\title{
'Written in Bone': New Discoveries about the Lives and Burials of Four Roman Londoners
}

\author{
By REBECCA C. REDFERN, MICHAEL MARSHALL, KATHERINE EATON \\ and HENDRIK N. POINAR
}

\begin{abstract}
The Museum of London selected four individuals for multidisciplinary scientific analyses in order to establish their ancestry, aspects of their personal appearance and health. We also reinterpreted their burial context in order to better understand how identity was constructed and expressed in this unique Roman settlement. Our study discovered the presence of people with Black and White European ancestry, some of whom had migrated from the southern Mediterranean. The most surprising result was that Harper Road woman's chromosomes were male. Overall, our experience of undertaking a multidisciplinary study served to further underline the need for these different techniques to be used in combination when investigating past identities. The $m t D N A$ results were very broad and required the mobility isotopes to better understand their significance, while the aDNA evidence confirmed the osteological analysis. In terms of public engagement at the Museum of London, the ability to determine hair and eye colour had a significant impact.
\end{abstract}

Keywords: Roman London; bioarchaeology; aDNA; stable isotopes; diet; mobility; funerary; grave goods; migration

\section{INTRODUCTION}

I n 2015, the Museum of London installed a temporary exhibition called 'Written in Bone' to share the results of recent collaborative projects with its audience and community stakeholders. Its purpose was to investigate the settlement of Londinium ${ }^{1}$ through the lives of four Londoners by examining where they had grown up and to establish aspects of their physical appearance and health using a variety of scientific methods. As the project was funded by the Museum's donors and collaborative research partners, the isotope and aDNA analyses

1 Background information about this settlement can be found in Perring 2004; 2015; Wallace 2015. Information about funerary practices and the cemeteries is described in Hall 1996. 
were focused on these questions rather than full genome sequencing as other studies have done for Romano-British populations in Britain. ${ }^{2}$

The Museum also used this opportunity to re-examine the funerary contexts and associated material culture of two males and two females in order to obtain a more nuanced and detailed insight into these objects and the role that they may have played in identity construction and expression. ${ }^{3}$ This article presents the details of this project and evaluates the utility of this approach for our understanding of Romano-British identities and for public engagement.

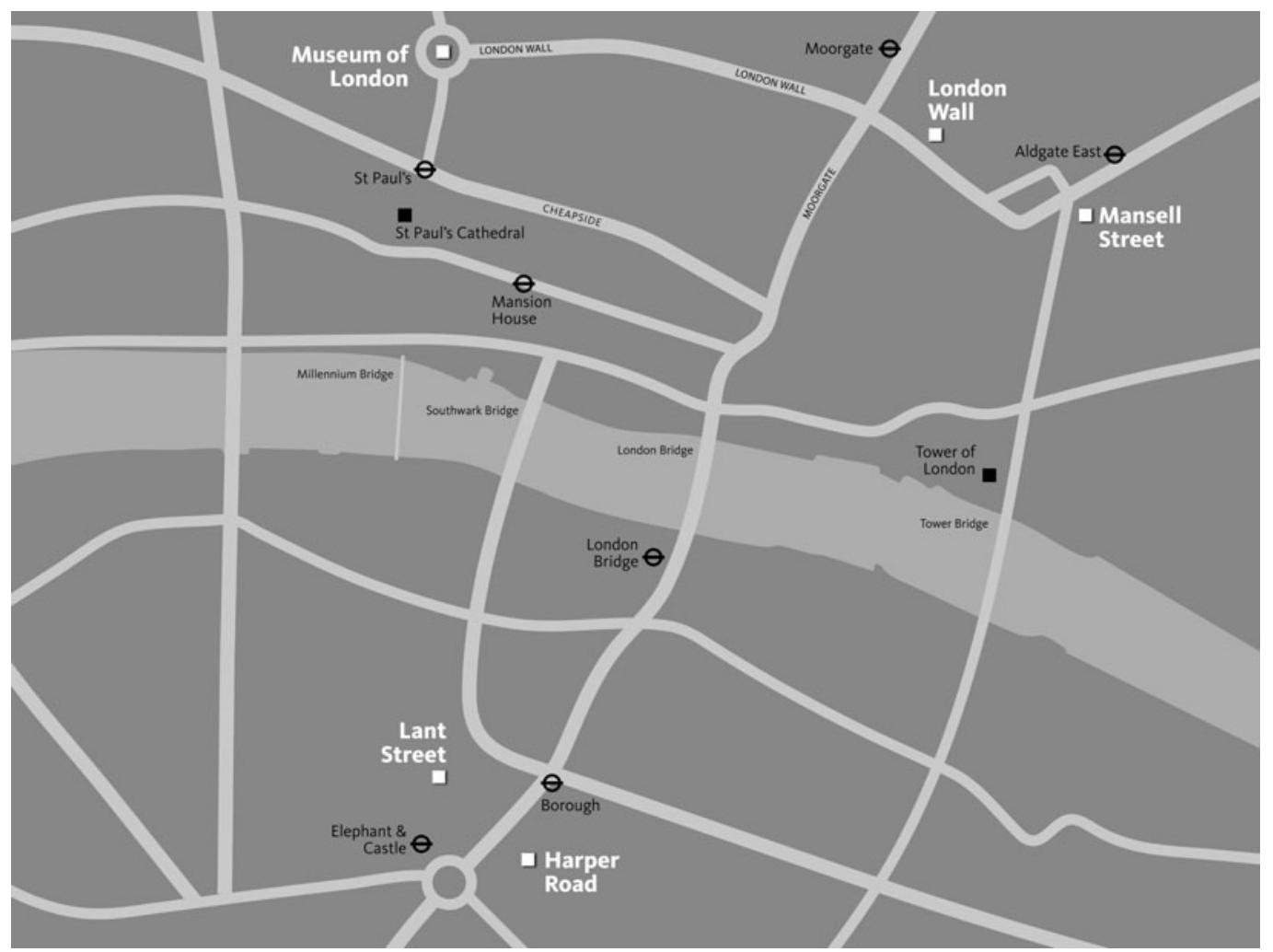

FIG. 1. Map showing the location of the sites in Roman London. (C) Museum of London)

MATERIALS AND METHODS

\section{OSTEOLOGICAL ANALYSES}

The four individuals selected for the exhibition were excavated from London (FIG. 1) between 1979 and 2003 and are curated by the Centre for Human Bioarchaeology (Table 1). The human remains were recorded by Redfern between 2008 and 2014 using the Wellcome Osteology

2 Martiniano et al. 2016.

3 In terms of the meeting of the social and physical bodies and how these are reflected in the funerary record, see Knudson and Stojanowski 2008; Gowland and Knüsel 2006a; Sofaer 2006. 
Research Database and the Museum of London methods. ${ }^{4}$ The age and sex of each individual were established using the standard osteological methods for assessing the morphological features of the skull and pelvis. ${ }^{5}$ Additionally, in order to further refine the age-estimations of the individual from Harper Road, ${ }^{6}$ the auricular ageing method devised by Buckberry and Chamberlain $^{7}$ was applied, while the sex of the adolescent from Lant Street (LTU03 sk 385) was estimated using the methods employed by Shapland and Lewis. ${ }^{8}$ The evidence for health and disease was recorded using the Museum of London methods, ${ }^{9}$ supported by in-house digital and film radiography of pathological bones. Ancestry was assessed using macromorphoscopics, rather than a metric-based approach, ${ }^{10}$ because the majority of the remains were fragmentary. This approach relies on the visual scoring of 16 cranial morphological features, the majority of which are found in the facial bones, with emphasis placed on the nasal area. ${ }^{11}$

TABLE 1. SUMMARY INFORMATION FOR INDIVIDUALS IN THIS STUDY

\begin{tabular}{|c|c|c|c|c|}
\hline $\begin{array}{l}\text { Site name and } \\
\text { context } \\
\text { information }\end{array}$ & Age, sex (*gender) and ancestry & Mobility data & $\begin{array}{l}\text { Dietary } \\
\text { data }\end{array}$ & Reference \\
\hline $\begin{array}{l}\text { Harper Road } \\
\qquad(\text { HR79 sk 311) }\end{array}$ & $\begin{array}{l}\text { White European woman* } \\
\text { (chromosomally male) aged } \\
21-38 \text { years old; brown eyes } \\
\text { and dark black hair }\end{array}$ & $\begin{array}{l}\delta^{18} \mathrm{O}_{\mathrm{p}} / \% \text { - } 10.8 ; \mathrm{Sr} \\
\text { concentration }(\mathrm{ppm}) \\
102 ;{ }^{87} \mathrm{Sr} /{ }^{86} \mathrm{Sr} 0.710110\end{array}$ & - & $\begin{array}{l}\text { Cotton 2008; Budd } \\
2003\end{array}$ \\
\hline $\begin{array}{l}\text { 52-63 London } \\
\text { Wall (LOW88 } \\
\text { sk 695.5) }\end{array}$ & $\begin{array}{l}\text { White European male aged } 36- \\
45 \text { years old; brown eyes and } \\
\text { dark brown hair }\end{array}$ & $\begin{array}{l}\mathrm{Pb} \text { concentration }(\mathrm{ppm}) \\
1.00 ; \mathrm{Sr} \text { concentration } \\
(\mathrm{ppm}) 137 ;{ }^{87} \mathrm{Sr} /{ }^{86} \mathrm{Sr} \\
0.70900\end{array}$ & - & $\begin{array}{l}\text { Lees et al. } 1989 \text {; } \\
\text { Redfern and } \\
\text { Bonney } 2014 ; \\
\text { Shaw et al. } 2016\end{array}$ \\
\hline $\begin{array}{l}\text { 65-73 Mansell } \\
\text { Street (MNL87 } \\
\text { sk } 37 \text { B604) }\end{array}$ & $\begin{array}{l}\text { Black male aged }>45 \text { years } \\
\text { old; brown eyes and dark } \\
\text { black/brown hair }\end{array}$ & $\begin{array}{l}\mathrm{Pb} \text { concentration }(\mathrm{ppm}) \\
3.05 ; \mathrm{Sr} \text { concentration } \\
(\mathrm{ppm}) 90 ;{ }^{87} \mathrm{Sr} /{ }^{86} \mathrm{Sr} \\
0.70933\end{array}$ & - & $\begin{array}{l}\text { Barber and } \\
\text { Bowsher } 2000 \text {; } \\
\text { Shaw et al. } 2016\end{array}$ \\
\hline $\begin{array}{l}\text { Lant Street } \\
\text { (LTU03 sk } 385 \\
\text { B15) }\end{array}$ & $\begin{array}{l}\text { White European female aged } \\
14 \text { years old; blue eyes }\end{array}$ & $\delta^{18} \mathrm{O}_{\mathrm{p}} / \%$ o 20.2 & $\begin{array}{l}\delta^{13} \mathrm{C} \\
-20.2 \text { and } \\
\delta^{15} \mathrm{~N} \\
10.9\end{array}$ & $\begin{array}{l}\text { Powell 2015; } \\
\text { Ridgeway et al. } \\
\text { 2013; Redfern } \\
\text { et al. } 2016\end{array}$ \\
\hline
\end{tabular}

\section{ANCIENT DNA ANALYSIS}

A molar tooth from each of the individuals was selected for ancient DNA analysis (aDNA), with the aim of determining the possible presence of bacterial, fungal and viral pathogens, identifying hair and eye colour, establishing sex using chromosomal markers and investigating maternal

$4 \quad$ WORD 2016 database. See Powers 2012; Connell and Rauxloh 2006.

5 Buikstra and Ubelaker 1994; Brickley and McKinley 2004.

6 This is the earliest burial from Roman London, and the Museum wished to know whether this individual would have been alive at the time of the Claudian invasion in A.D. 43.

7 Buckberry and Chamberlain 2002.

8 Shapland and Lewis 2013; 2014. This research is published by Arthur et al. 2016. The methods used to determine sex have been published by Bass 2005; Buikstra and Ubelaker 1994; Genovés 1959; Phenice 1969; Rogers 1999; 2009 ; Schutkowski 1993; Walker 1995; Weaver 1980.

$9 \quad$ Martiniano et al. 2016.

10 Such as the CRANID or FORDISC programmes which are based on measurements of the skull.

11 Hefner et al. 2012; Hefner and Ousley 2014. See also Redfern et al. 2016. 
ancestry (mtDNA) based on complete mitochondrial genomes. A detailed description of the methods employed is published on the Museum's website, ${ }^{12}$ with only a brief overview being provided here.

All the subsampling and labwork was performed at the McMaster Ancient DNA Centre. ${ }^{13}$ The human mitrochondrial bait set chosen for this project had previously been designed using Human mitochondrial rCRS GenBank Accession number J01415.2, which suggests possible localities of the haplogroups $c$. 500 years ago, prior to the era of intercontinental travel. Hair and eye colour was identified using a modified version of the HIrisPlex SNP assay designed for targeted enrichment in the ancient DNA lab. ${ }^{14}$ The sex chromosome typing baits targeted three $\mathrm{Y}$ chromosome-specific genes (AMELY, SRY and TSPY) and two X chromosome-specific genes (AMELX, SOXL3). Gene sequences and NCBI genbank annotations for the five sex-linked genes were downloaded from RefSeq and targeted regions were obtained from previously published loci. ${ }^{15}$ The presence of viral (e.g. smallpox) and bacterial (e.g. plague, tuberculosis) diseases was determined using a modified version of an array-based method for the detection of pathogens in ancient remains ${ }^{16}$ and the methods described by Marciniak. ${ }^{17}$

\section{STABLE-ISOTOPE ANALYSIS OF DIET AND MOBILITY}

The stable-isotope analysis was undertaken during the course of three separate studies over the past 15 years, with different isotopes used to investigate diet and mobility in these individuals. ${ }^{18}$ As the isotope study of the Harper Road woman had been undertaken some years ago and because the Museum was reluctant to undertake further destructive analysis on her last remaining tooth, the original mobility data ${ }^{19}$ were re-interpreted by Montgomery. ${ }^{20}$

Analysis of childhood residency was undertaken using oxygen $\left(\delta^{18} \mathrm{O}\right)$, strontium $\left({ }^{87} \mathrm{Sr} /{ }^{86} \mathrm{Sr}\right)$ and lead $\left(\delta^{207} \mathrm{~Pb}^{1206} \mathrm{~Pb}\right.$ and $\left.{ }^{208} \mathrm{~Pb} /{ }^{206} \mathrm{~Pb}\right)$ isotopes extracted from the dental enamel, with dietary isotopes of carbon $\left(\delta^{13} \mathrm{C}\right)$ and nitrogen $\left(\delta^{15} \mathrm{~N}\right)$ extracted from rib bone samples for the individual from Lant Street. ${ }^{21}$ The methods used to establish the local/non-local origin of the Harper Road individual are described in Budd, ${ }^{22}$ the London Wall and Mansell Street burials by Shaw and colleagues, ${ }^{23}$ and the Lant Street adolescent by Redfern and colleagues. ${ }^{24}$

Available at http://blog.museumoflondon.org.uk/written-bone/.

McMaster University, Hamilton (ON Canada) http://socserv.mcmaster.ca/adna/.

Walsh et al. 2013.

Butler and Li 2014.

Devault et al. 2014.

Marciniak et al. 2016.

During this time, stable-isotope methods have developed very rapidly. Today, researchers in this field recommend using combinations of different isotopes (i.e. oxygen, lead and strontium) to achieve the most detailed information about a person's mobility. Nevertheless, raw data can be reliably recalculated in order to give the most up-to-date interpretation, as in this study.

19 Unpublished report held by the Museum of London. The laser ablation method was used in this case.

20 Janet Montgomery, pers. comm.

21 Powell et al. 2014.

22 Budd 2003. The laser ablation method was used in this case. The 1 st molar of HR79 sk 311 was analysed: $\delta^{18} \mathrm{O}_{\mathrm{dw}}$ SMOW -10.8\%o, Sr $102 \mathrm{ppm},{ }^{87} \mathrm{Sr} /{ }^{86} \mathrm{Sr} 0.710110, \mathrm{~Pb} 0.21 \mathrm{ppm}$.

23 Shaw et al. 2016.

24 Redfern et al. 2016. 


\section{RESULTS}

This burial is one of the earliest from Londinium, dating from A.D. 50-70. It was located in Southwark (FIG. 1) and excavated in 1979 as part of student training by the Southwark and Lambeth Archaeological Excavation Committee. ${ }^{25}$ The grave was aligned on a north-east/ south-west axis and the cut was c. $2.3 \mathrm{~m}$ long by $1.0 \mathrm{~m}$ wide. The skeleton had been placed on one side, in an extended position, with the skull orientated to the south-west; nails of various sizes (including one $101 \mathrm{~mm}$ in length) recovered from the grave fill may indicate the presence of a coffin. ${ }^{26}$ The burial was also accompanied by several objects usually associated with a 'female' gender, some deemed 'indigenous' and others 'Roman', which are discussed below.

Bioarchaeological analysis revealed that the skeleton was an adult aged c. 21-38 years old, whose skull and pelvic morphology were determined to be female. ${ }^{27}$ Unexpectedly, aDNA analysis identified male chromosomes (XY), with the expected number of reads for a genetic male in the X-chromosome regions (AMELX and SOX3) and Y-chromosome regions (SRY, TSPY, AMELY). This result does not mean that the bioarchaeological or aDNA data are incorrect; rather it suggests that this individual likely had a sex development disorder. Today, the incidence of such disorders is 1:4,000 to 1:5,000 live births, the signs of which can either present at birth or develop during childhood and adolescence. ${ }^{28} \mathrm{We}$ do not enter into speculation about this person's physical appearance, as the specific disorder could not be established and it was not possible to explore this further with aDNA due to limited resources for the current project. What is clear is that this individual was identified as a woman by her community, ${ }^{29}$ a decision that we continue here and at the Museum in her display and gallery

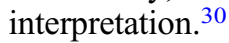

Unfortunately, none of the long bones were complete enough to estimate stature. The assessment of ancestry suggested that she was White European, while the HirisPlex test found that she had brown eyes and dark black hair. Her maternal haplotype was determined to be H2a2a1 whose geographic distribution (c. 500 years ago) covers eastern Europe, the Caucasus and Central Asia. ${ }^{31}$ A re-evaluation of the stable isotope evidence for mobility suggested that in all likelihood she grew up in Britain.

The evidence for disease was limited to some degeneration in the joints, commonly observed in archaeological populations: a rotator cuff injury on the lesser tubercle of the left humerus, caused

25 Cotton 2008, 151.

26 ibid., 158.

27 Observable scores $(1=$ male, $2=$ p.male, $3=$ intermediate, $4=$ p.female, $5=$ female). In the skull (overall score 4$)$ : supra-orbitalia ridges and forehead (5), mastoid process, inion protuberance (3), zygoma root (2). Pelvis (overall score 5): greater sciatic notch and pre-auricular sulcus (5). Note that the cranium has been reconstructed and overall the skeleton has 'moderate' bone preservation. These scores are within the 'female' range for Roman London but, based on the author's experience, also for elsewhere in Roman Britain and for late Iron Age populations.

28 Warne and Raza 2008.

29 Following Geller 2017, 4-6, 46; see also Arnold 2002. To the best of our knowledge, the late Iron Age sword and mirror burial from the Isles of Scilly (Johns 2006, see also the discussion by Jordan 2016) is the only example of masculine and feminine items being included in the same grave context — in this case, aDNA and osteological analysis was unable to determine the sex of the individual in this burial. Funerary analyses of Iron Age populations from east Yorkshire (Giles 2012) and Dorset (Hamlin 2007) have not found any discrepancies between the sex of the individual buried in the grave and the gendered grave goods accompanying them.

30 See Geller's 2017, 13-15 discussion of the mediascape which we encountered during this exhibition, for example the comments on a piece featured in the Daily Mail http://www.dailymail.co.uk/sciencetech/article-3361146/TheRoman-Woman-MALE-DNA-Analysis-2-000-year-old-skeleton-reveals-physical-female-traits-genetically-man.html.

31 The mitochondrial aDNA evidence from Londinium is similar to work reported from elsewhere in Britain and Italy (Catalano et al. 2001; Martinano et al. 2016), whereby people have evidence for complex maternal ancestries that reflect not only population movement within the Empire but also episodes of migration in earlier periods. 
by a fall or else through over-use of the shoulder-joint, and degenerative changes to one cervical and one lumbar vertebra. ${ }^{32}$ Only nine dental positions and three teeth were observable, but only one dental position had evidence for disease - periodontitis, a common infection of the gums. ${ }^{33}$ No aDNA evidence for bacterial or viral diseases was found.

Her burial includes an important group of grave goods which have been the subject of a careful assessment by Cotton and this is expanded upon here (FIG. 2). ${ }^{34}$ A group of Claudio-Neronian pottery reflects access to imported vessels and perhaps the adoption of continental styles of dining. As Bird, Hall and Cotton suggest, some vessels may also have been carefully selected for inclusion in the burial because they were stamped with the potter's name Vitalis, perhaps a play on the words for life and vitality, which would indicate literate mourners with a relatively sophisticated knowledge of Latin. ${ }^{35}$ A rectangular mirror placed at her feet implies the deliberate construction of identity through grooming and, as examples from Iron Age and Roman burials tend to be associated with females, this object also has gendered connotations. ${ }^{36}$ Grooming practices may have been very visible symbols of personal cultural preferences in this early period, as some, such as arrangement of the hair using hairpins, were new introductions to Britain from the Continent, ${ }^{37}$ while others, such as the preparation of cosmetics in two-piece copper-alloy sets, had a strong local Iron Age pedigree. ${ }^{38}$ But while the mirror is a Roman type, it provides no real hint as to whether Harper Street woman used it according to indigenous practices or in a more 'Romanised' manner. ${ }^{39}$

The single most distinctive object is the bronze penannular neck ring/torc (FIG. 3), which was broken and placed near to the mirror. The torc was rectangular sectioned with squared terminals and decorated with a ring-and-dot pattern on the hoop and feather motifs and transverse hatched bands at the terminals. ${ }^{40}$ Cotton has argued that it was a 'pidgin' object, a 'single creative response to a particular situation at the very beginning of Roman contact'. ${ }^{41}$ While the find remains unique, we can now better situate it through comparison with two other classes of personal ornament, with which it would seem to be closely related. The first is a contemporary group of penannular strip armlets whose form and decorative vocabulary are closely related to the torc. These are distributed in south-eastern Britain, including London, but are particularly focused around Hertfordshire and East Anglia in the territory of the Trinovantes and the Catuvellauni. ${ }^{42}$ The second type is represented by several copper-alloy penannular torcs of slightly different form, recently

32 Roberts et al. 2007.

33 Hillson 2005, 260-8.

34 Cotton 2008.

35 ibid., 159-60; archaeological finds from the city suggest relatively widespread literacy as suggested by the number and range of inscriptions (Holder 2007) and the large number of writing-tablets from the city (Tomlin 2016).

36 For Iron Age Mirror burials Joy 2007, 169-215; 2010. He identifies six female or possible female associations and only one possible exception from the Late Iron Age cemetery at King Harry Lane, Verulamium, where a circular Roman disc mirror was found in a possible male cremation (Stead and Rigby 1989, 103, d no. 2 and 277-8, fig. 91, burial 13.6). However, further ambiguity is provided by the burial on Bryher (Johns 2006; see also Jordan 2016). For Roman burials with mirrors, again female where it can be determined, see Philpott 1991, 277-8 and 355, tables A11 and A32. For an example from Roman London see Whytehead 1986.

37 See Hall and Wardle 2005, 25-7, nos 1-12 for examples of hairpins from the city, some of which are self-referential objects depicting female busts with Roman hairstyles.

38 Jackson 2010, 148-51, nos 319-28.

39 Cotton 2008, 156-7, table 3.6.1 and fig. 3.6.3, no. 4. As Lloyd-Morgan 1981, 3, group A. Roman style mirrors already appear in pre-conquest Iron Age burials (Stead and Rigby 1989, 103) and, in this case, the mourners may well have been familiar with how the mirror was used by Harper Road Woman.

40 Cotton 2008, 155-9, table 3.6.1, fig. 3.6.3, no. 3 and fig. 3.6.4.

41 ibid., 155.

42 Crummy 2005a, 93-4, fig. 2. The closest connection between the Harper Road torc and this series of bracelets comes from their penannular construction, squared-off terminals with double bands of transverse decoration (compare Crummy 2005a, 95, fig. 3 generally) and the patterns of ring-and-dot motifs joined by incised lines (ibid., 95, fig. 3, nos 15 and 28). 


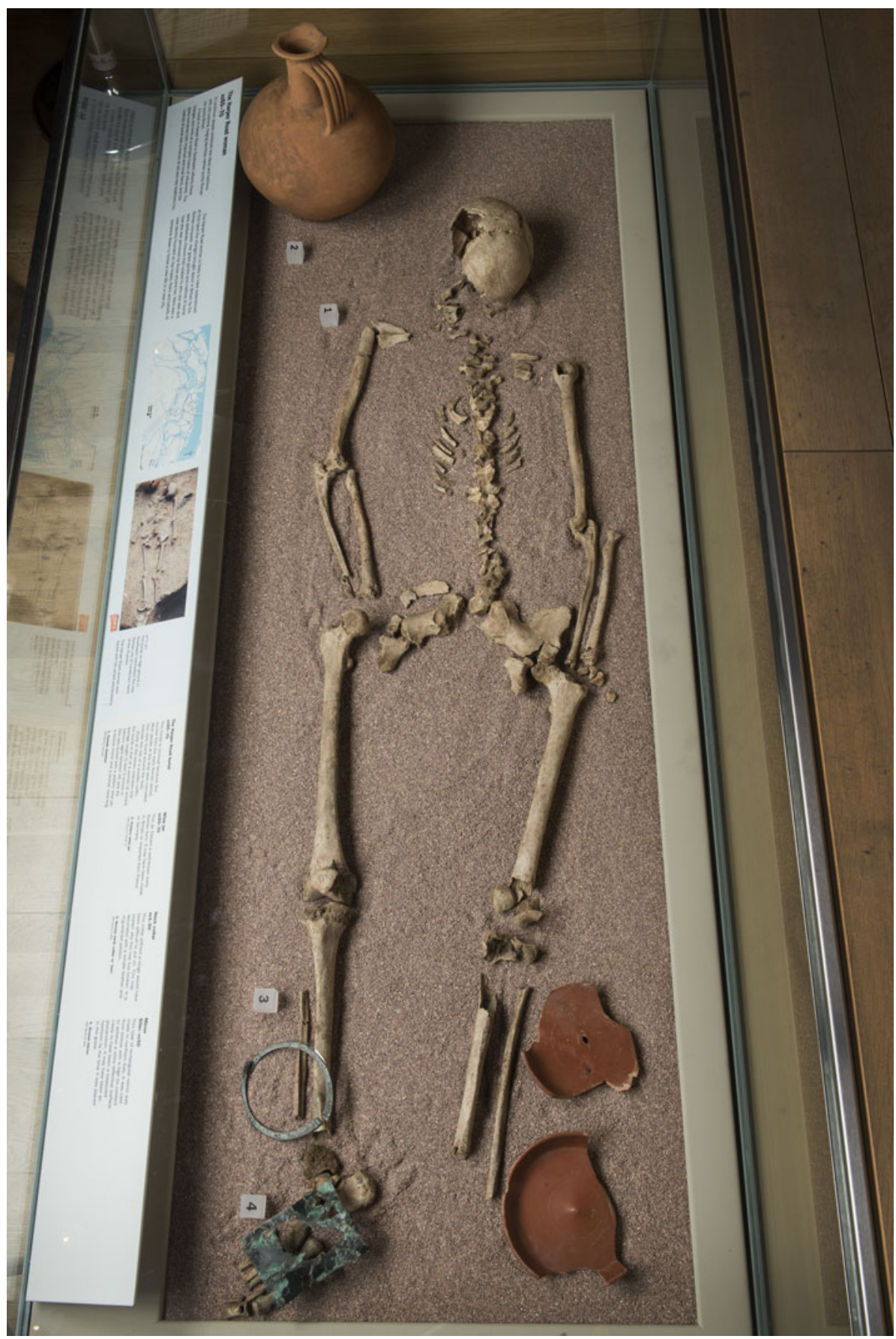

FIG. 2. Superior view of the reconstructed burial from Harper Road (HR79 sk 311). (C Museum of London) 
excavated from Baldock (Herts.) by the Heritage Network and awaiting publication, which have similar 'feathered' motifs on the terminals. ${ }^{43}$

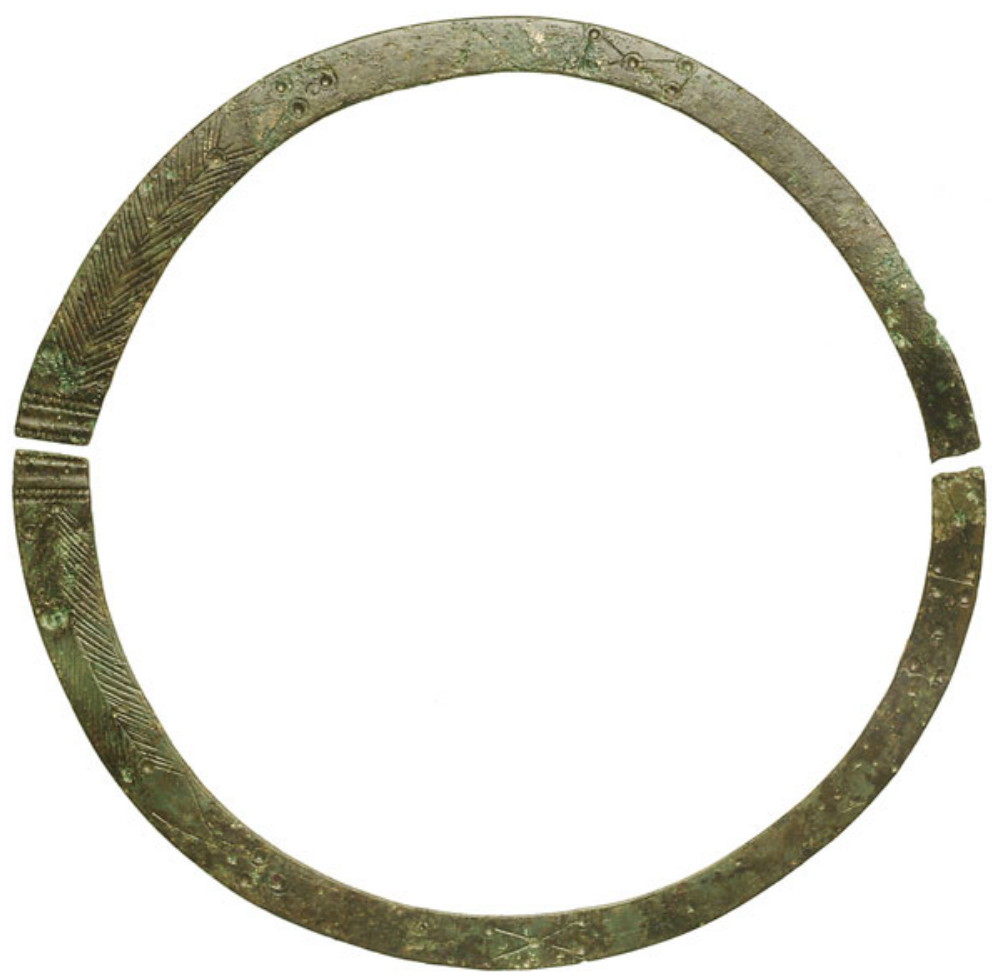

FIG. 3. The torc from the Harper Road burial. (c) Museum of London)

The Harper Road torc can, therefore, be seen to be closely associated with a regionally distinct group of objects focusing on body care and decoration, although its precise significance remains ambiguous. Similarly regionalised dress traditions were arising across Britain at this time and several include new styles of torc/neck ring, often alongside the prominent use of Celtic art, which may perhaps indicate a stress on local identities in response to the Roman conquest. ${ }^{44}$ The South-East has largely been excluded from such discussions, but it is possible that this group of material represents a comparable phenomenon, although the relatively short-lived nature of this group and the character of the decoration which eschews the same prominent use of insular La Tène art is rather different. This may relate to the specific local social context, particularly the speed of the initial conquest in the South-East and the huge influx of 'Roman' material culture, well represented in the Harper Road burial, which offered alternative sources

43 Wardle forthcoming. Both torcs were found with female/probable female individuals, Heritage Network pers. comm. We are grateful to Angela Wardle for bringing this important find to our attention and to Helen Ashworth for permitting us to mention it here in advance of publication. Full analysis of the finds is yet to take place but it can be no accident that this find falls within the core distribution of the penannular armlets, examples of which are known from the same site (Crummy 2005a, 100, nos 15-18; Stead and Rigby 1986, fig. 52, nos 163-6).

44 Nowakowski et al. 2009; Hunter 2010. 
of inspiration and competing avenues for the expression of power and prestige. ${ }^{45}$ In fact some of the decoration could be seen as continental in inspiration; indeed Crummy has made a strong case that, while the armlets are a Romano-British regional phenomenon, they may have actually been armillae worn by Roman soldiers, battle honours from early campaigns in Britain, on the basis of the distribution and decoration, which includes cross-cut bands that could be interpreted as wreath motifs perhaps with connotations of victory. ${ }^{46}$ Interestingly, the decorative emphasis of the Harper Road find is slightly different, with the wreaths all but absent. The feather or perhaps palm motifs found on some of the bracelets are enlarged and elaborated, more closely matching the Baldock torc. Cotton has gone as far as to suggest that these represent peacock feathers, which in a Classical tradition have connotations of immortality, apposite in a funeral context, as well as connections to the goddess Juno, protector of women. ${ }^{47}$

We are left with two related interpretative possibilities. The first is a torc that belongs to a continentally influenced local dress tradition, which may in turn have influenced the design of British armillae found in the area. The second is a torc closely related to the local Baldock finds but which also draws upon Classical imagery and the specific provincial aesthetic model of the armillae worn by the Roman soldiers and veterans who would have been frequently encountered in places like Londinium. Such imitation may be taken as an acknowledgement of the power of these individuals, but if transformed into a 'native' torc worn by a woman and arguably with 'feminised' peacock iconography could alternatively be seen as a powerful subversion of male military symbolism. ${ }^{48}$

In light of these findings, we support Cotton's assertion that this woman's burial is a response by indigenous communities to the rapidly changing world of first-century south-east Britain. ${ }^{49}$ The richness of the burial and the objects included within support the evidence for female power and agency in late Iron Age societies and hint at her status and role within her community. During periods of colonisation it is women, more so than men, who act as crucial intermediaries between cultures. ${ }^{50}$

\section{2-63 LONDON WALL (LOW88 sk 695.5)}

This individual was recovered from a pit in association with other disarticulated human bones from an industrial and domestic site in the Walbrook valley, close to the Walbrook stream and dates to A.D. 125-200 (FIG. 1). ${ }^{51}$ During this time, this part of London was an important industrial area for the manufacture of glass, metal-, wood-, leather- and bone-working and a dumping area for waste. However, in the upper part of the valley (outside the settlement's walls), it was an important ritual

45 Hunter 2008.

46 Crummy 2005a, 98-100. Crummy cites two penannular armlets from London to which at least four more can be added from modern excavations in the Middle Walbrook valley which have produced extremely large groups of contemporary militaria at 1 Poultry (Hill and Rowsome 2011, 26) and Bloomberg London (Marshall and Wardle in prep.). See also Crummy 2016, 7-11.

See Cotton 2008, 155 and Toynbee 1973, 251 for discussion of peacock iconography. In assessing the likelihood of this complexity of Classical allusion, it should be stressed that even if this is in some sense a 'native' or 'Celtic' find, it is one found in a Roman urban centre which may have been deposited as much as 25 years after the conquest providing ample opportunity for an individual of some means to develop a knowledge of aspects of Classical culture.

48 Whether or not it would be safe to try and subvert or even pastiche a symbol of Roman military achievement in the tense post-conquest years is of course questionable and for this reason this option must be considered the least likely of the two. In light of her chromosome results, it also raises questions about her physical appearance and social identity.

49 Cotton 2008.

50 Pope and Ralston 2012. As proven in many anthropological and ethnohistorical studies, among others, Shoemaker 2012.

$51 \quad$ Lees et al. 1989; Redfern and Bonney 2014. 
space used as a cemetery and for the deposition of votive offerings. ${ }^{52}$ The site was located within the Roman city walls, hence the evidence of clay-and-timber buildings and a gravel road, as well as amphorae, glassware, a wooden bowl and utensil, bone hairpins, an ivory bracelet, decorative copper-alloy mounts, many shoes (e.g. a soft one-piece moccasin), copper-alloy coins and a writing implement. ${ }^{53}$ The cranium was recovered from an oval-shaped pit which was 3.40 by 2 $\mathrm{m}$ and $0.50 \mathrm{~m}$ deep, suggesting that it was not dug as a waste pit. It was filled with silt and contained a minimum number of ten adult male crania (no mandibles were recovered) and one adult right femoral shaft. These crania had evidence for extensive and lethal peri- and ante-mortem blunt and sharp-force injuries and have been interpreted as victims of ritualised and structural violence, either as headhunted victims of the Roman army, executed prisoners or defeated gladiators. ${ }^{54}$

Bioarchaeological analysis determined that the cranium was of a male (this time supported by the chromosome results XY), aged 36-45 years old. Assessment of ancestry determined that he was White European, while the HirisPlex test found that he had brown eyes and dark black hair. His maternal haplotype was J1b1a1, which has a very wide distribution (c. 500 years ago) across Europe, North Africa, the Near East and the Caucasus. ${ }^{55}$ The mobility isotope results were sadly inconclusive for this individual. He has a low lead concentration $(1 \mathrm{ppm})$ that places him on the edge of the anthropogenic English lead ore field, but too close to the culturally defined parameters for Roman Britain to exclude him definitely from being British, while his strontium result falls within the London region, though these values are also found in many parts of Europe. ${ }^{56}$

He had poor dental health, as calculus, carious lesions and periodontal disease were observed; the latter was also identified using aDNA, as Tannerella forsythia, Treponema denticola, Porphymonas gingivalis and Fusobacterium nucleatum were present. These dental diseases are frequently encountered in Romano-British and Roman urban populations. ${ }^{57} \mathrm{He}$ also experienced episodes of compromised health during childhood, as his dentition had evidence for enamel hypoplastic defects, while healed cribra orbitalia and porotic hyperostosis were present to several of his cranial bones. These diseases have multifactorial origins, including periods of ill health, anaemia, a heavy parasite load and compromised nutrition. ${ }^{58}$ Environmental and other bioarchaeological data from Britain attest to the presence of parasites and the frequent occurrence of these diseases in both rural and urban populations. ${ }^{59}$

The majority of observed pathology related to violent injuries, including a healed fracture to his left zygomatic bone, an injury typically produced during assaults. ${ }^{60}$ Dental chipping is also present, which has a multifactorial origin but can be caused by blows to the face. ${ }^{61}$ Most of the injuries to his cranium were sustained shortly before or at the time of death, with multiple blunt-force fractures observed to the facial area and right temporal bone, attesting to the individual having sustained numerous direct blows to the face ${ }^{62}$ (FIG. 4).

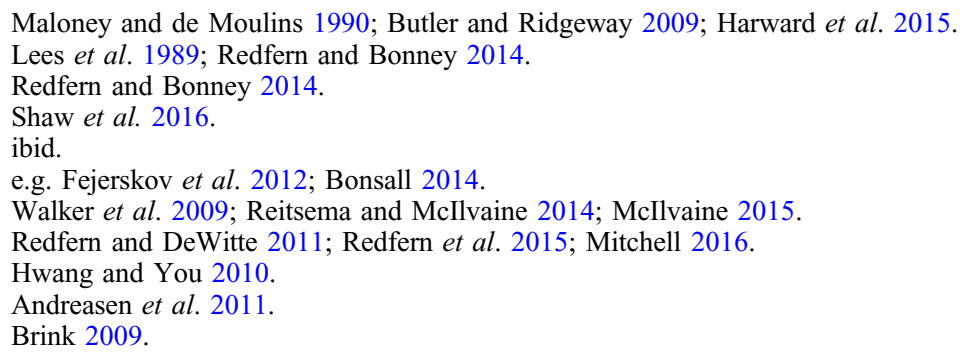




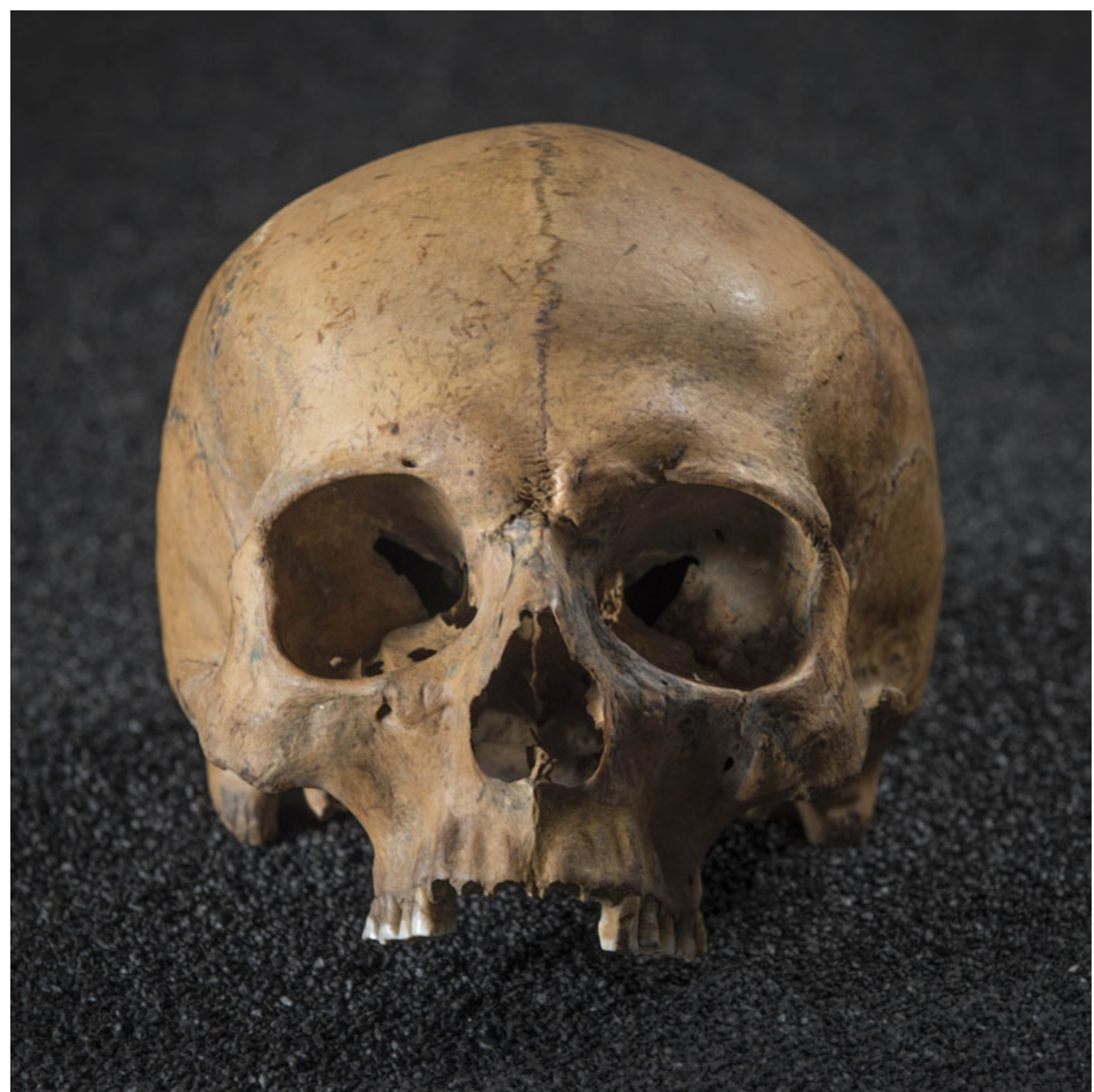

FIG. 4. Anterior view of the male cranium (LOW88 sk 695.5) showing evidence for dental chipping and injuries to the facial cranial bones. (C) Museum of London)

Peri-mortem injuries of this nature are not observed in the normative cemetery populations of Londinium. Although many males have healed fractures produced by inter-personal violence such as nasal bone fractures, there is not the same evidence for this degree of 'over-kill' in the other individuals. ${ }^{63}$ This reinforces the atypical and unusual injury pattern and types of violence observed at London Wall. There was no taphonomic evidence from this cranium or others in the same context to suggest that the remains had been carried to the site by water-action. ${ }^{64}$ Therefore, it is most likely that along with the partial remains of nine other men, his cranium

64 Redfern and Bonney 2014. 
had been collected from elsewhere in the settlement and deposited in a specially dug pit in the Walbrook valley. The inconclusive stable-isotope results mean that unfortunately we are unable to clarify the possible reason for his death (i.e. trophy head).

\section{5-73 MANSELL STREET (MNL87 sk 37 B604)}

This burial was part of the 'Eastern' burial ground of Londinium, located to the south of a spur-road off the main road from the settlement which leads to Colchester (FIG. 1). ${ }^{65}$ The area is divided into two plots, defined by the presence of the road and two ditches (one east-west, the other north-south) that show evidence for maintenance, being redug and cleaned on several occasions, supporting the suggestion that the burial grounds along this important road were formally managed. 66 The burial plots were in use between the second and fourth centuries, with this burial being assigned a date of A.D. 180-400. ${ }^{67}$ The burial had been heavily truncated in later periods by the digging of a gravel pit and concrete foundations. The individual had been laid out in a supine position with the head orientated to the west; no extant grave goods were observed, though it is possible that existing goods were destroyed during these periods of disturbance. ${ }^{68}$

The damage to the grave meant that the human remains were limited to a highly fragmentary axial skeleton (skull, thorax, spine and pelvis) (FIG. 5). Analysis estimated this individual to be a male (supported by the genetic results), aged over 45 years old, who had Black ancestry, while the HirisPlex analysis found that he had brown eyes and dark black/brown hair. His maternal haplotype was V16, which is evenly distributed across Europe and North Africa (c. 500 years ago), with the stable-isotope results showing that he had spent his childhood in the London region. ${ }^{69}$ The presence of people born in London with African ancestry is not an unusual or atypical result for Londinium, as a multidisciplinary study of a southern cemetery has found, ${ }^{70}$ nor for other urban centres in Britain, as with the female known as the 'Ivory bangle Lady' from Eboracum (York). ${ }^{71}$

The fragmentary and truncated nature of this male's skeleton meant that some health indicators such as cribra orbitalia were not observable, because the roofs of the eye sockets were not present. Examination of the extant dentition showed that he suffered from calculus, carious lesions and associated periapical abscesses but also periodontal disease, which was also attested in the aDNA results that detected the presence of Tannerella forsythia, Treponema denticola and porphyromonas gingivalis. As above, these are frequently observed diseases in Romano-British populations.

The male also suffered from osteoarthritic conditions of the spine, as degenerative changes were observed to the cervical, thoracic and lumbar vertebrae; also present from the 7 th to 11 th thoracic vertebrae (mid to lower chest area) was Diffuse Idiopathic Skeletal Hyperostosis (DISH) (FIG. 5), a condition which causes ossification of the ligaments, particularly the spinal column, and is related to age. ${ }^{72}$ Previous palaeopathological studies suggested a link between DISH and a rich diet/ obesity, but these have been rejected in light of more recent research and clinical findings that

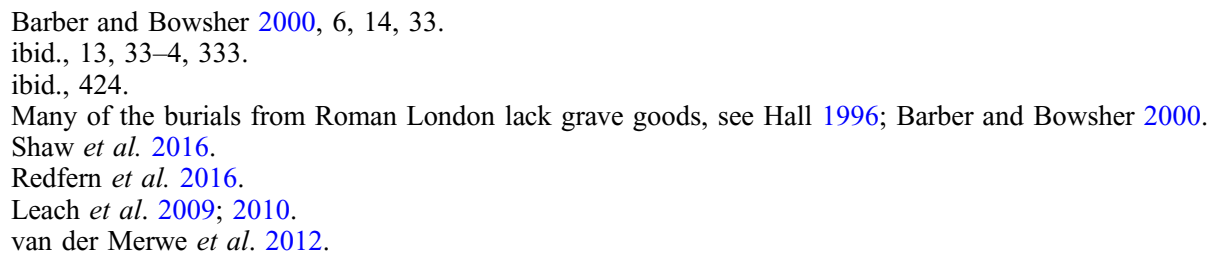




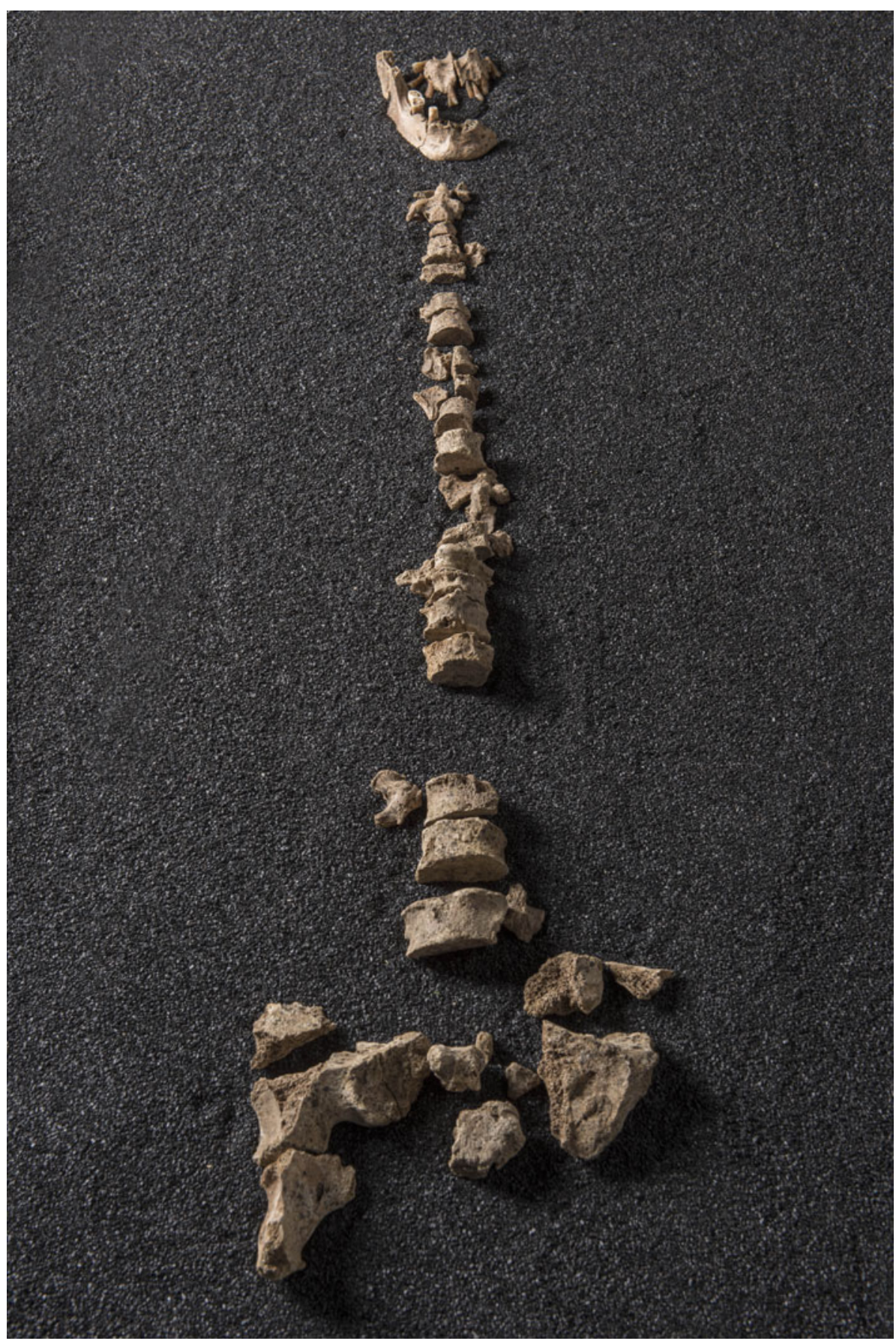

FIG. 5. Skeleton of the adult male (MNL87 sk 37 B604) from Mansell Street. (C Museum of London) 
have identified low serum levels of the natural osteogenesis (bone formation) inhibitor Dickkopf-1 (DKK-1) in sufferers of this disease. Much of the earlier data regarding the co-existence of DISH, diabetes and obesity were derived from North American populations. ${ }^{73}$ The fusion of multiple vertebrae would not have been particularly debilitating, but he is likely to have experienced stiffness to his back. ${ }^{74}$

His health and mobility were further compromised by the presence of Paget's disease in the 9th to 12 th thoracic vertebrae, the pelvis and right portion of the mandible (FIG. 5). ${ }^{75}$ This disease causes bone deformity, because the balance of bone remodelling is affected, whereby bone tissue is destroyed in specific areas (e.g. pelvis, spine and skull), followed by a period of abnormal bone formation, creating bone which is weaker. The sufferer may be asymptomatic, or experience bone pain, joint stiffness, have warm skin over the affected bones and skull enlargement and deformities. ${ }^{76}$ Interestingly, clinical research by Morales and colleagues ${ }^{77}$ found that sufferers of Paget's were more likely than a control group to have DISH, suggesting that there may be a genetic mechanism which makes Paget's disease sufferers more susceptible to developing DISH. Regrettably, these two diseases could not be explored at a genetic level in this male.

Our research has been able to establish certain aspects of this man's physical appearance and compromised mobility as contributing to aspects of his identity and life experience. At present, he is the only individual from Londinium to present with both DISH and Paget's disease and the only male to be diagnosed with Paget's disease. ${ }^{78}$ However, the disturbed and truncated nature of his burial context prevents us from exploring social aspects of his identity, such as status. ${ }^{79}$ The extant information suggests that he is typical of the many hundreds of Roman burials from Londinium.

\section{2-56 LANT STREET (LTU03 sk 385, B15)}

The burial was located in a cemetery in the southern settlement of Londinium, Southwark, and was excavated by Pre-Construct Archaeology in 2003 (FIG. 1). This cemetery area was first established in the late first to second centuries. Following a hiatus in the burial record, burial begins again at the site in the mid-third century and extends into the early fifth century. ${ }^{80}$ The site developed into a large managed cemetery, with the richest burial belonging to this person; ${ }^{81}$ the original publication assigned the burial to the fourth-century phase of activity on the site, although the dating of the grave goods may support a slightly earlier, third-century date. ${ }^{82}$

73 The dominance of studies from the USA has caused a bias in the clinical literature. Mays 2006; Spencer 2010; Mazieres 2013.

74 Terizi 2014

75 This was identified macroscopically and using digital radiography.

76 Kotowicz 2004.

77 Morales et al. 1993

78 WORD 2016; the only other case of Paget's was observed in a 36-45-year-old female (HOO88, sk 518).

79 In our view, the compromised funerary context prevents us from asserting whether he was of free or enslaved status, or associated with the military etc.

80 Ridgeway et al. 2013, 1, 3.

81 ibid., 16-19.

82 Shepherd (2013, 36 and 40-2) suggests a second-/third-century date for the glass vessels on stylistic grounds. Elsewhere Crummy 1983, 126 suggests a date from the mid-second century onwards for keys with trefoil handles. Clasp knives are used for much of the Roman period but examples carved in the round such as this are typically of second- or third-century date (von Mercklin 1940; Bartus 2007). Greep 2004, 274-5 discusses the dating of bone veneer such as that found on the Lant Street box and notes that, setting aside a very distinctive early group, most examples are of third- or fourth-century date with a group that probably derives from funerary furniture in the third century and another that probably derives from boxes and other pieces of furniture that seem to belong mostly to the later third and fourth century. Taken altogether a third-century date for the burial seems most probable although a fourth-century burial incorporating old finds cannot be ruled out. 
The bioarchaeological analysis of the skeleton revealed a 14-year-old girl, a result supported by the chromosomal results XX. Her ancestry was determined to be White European, while the maternal haplotype was HV6, which (c. 500 years ago) is found in southern and eastern Europe, west Asia and north-east Africa. The HirisPlex test could only identify her eye colour with certainty, which was blue. Initially, it was suggested that she originated from North Africa, ${ }^{83}$ but a revised interpretation of her stable-isotope results for mobility found that she had spent her younger childhood in the southern Mediterranean. ${ }^{84}$ Dietary isotopes taken from rib bone (Table 1) indicated that she had been consuming terrestrial and marine resources local to the area. Bone turnover rates for the rib were estimated as an average of five years, meaning that she had lived in Londinium at least since the age of nine. ${ }^{85}$

Her dentition revealed very poor dental health, as multiple dental caries were present, as well as calculus and periodontal disease - Tannerella forsythia, Treponema denticola and Fusobacterium nucleatum were detected using aDNA techniques. Several of the large carious lesions affected the first mandibular molars whose crowns were also severely affected by enamel hypoplastic defects. The thin and defective enamel in these teeth would have increased her risk of forming caries, because the crown would have been more vulnerable to decay. ${ }^{86}$ The enamel hypoplastic defects were more severe than observed in other subadults from Londinium, with lines of exposed dentine observable to the naked-eye, most notably to the right maxillary first incisor, which also had a talon cusp present. This is a very rare non-metric dental trait and is characterised by a large, additional, projecting cusp on the lingual aspect of the tooth. ${ }^{87}$ It is more frequently observed in females, with the maxillary incisors most commonly involved. ${ }^{88}$ Other minor congenital conditions were observed in her skeleton, including an extra vertebra and partial union of some of her foot bones. ${ }^{89}$ These conditions have a hereditary component but can also be caused by minor environmental disruptions during embryogenesis; ${ }^{90}$ only the changes to the foot bones are likely to have impacted mobility, as this will have caused minor restriction to movement, though this may not have been detectable in everyday life. ${ }^{91}$

Evidence for remodelling new bone was also observed to the legs, particularly the medial aspect of the tibiae (lower leg). This is a non-specific reaction to an unknown disease process, but the remodelling nature of the bone suggests that she was recovering from this health condition. ${ }^{92}$ The radii and ulnae bones of the forearms display very mild anterior-posterior and lateral plastic bowing, while the shafts of the femora also show mild anterior-posterior bowing; no evidence for healed injuries was observed radiographically. This represents a remodelled case of mild rickets ${ }^{93}$ and, given that the changes are limited to the forearms and thigh bones, it is likely that she developed this metabolic disease when she was a crawling baby. Rickets was a disease recognised by Roman medical writers, who noted that toddlers in the city of Rome frequently developed the disease, but because the cause was unknown (see Rohnbogner's

\footnotetext{
83 Ridgeway et al. 2013, 65-70.

84 Redfern et al. 2016.

85 Powell 2015.

86 Seow 2014; Targino et al. 2011.

87 Sumer and Zengin 2005.

88 ibid.

89 She has bilateral non-fibrous coalition of calcaneus-cuboid and navicular-third cuneiform facets on the foot bones, mild lumbarisation of the 12th thoracic and the presence of an 6th lumbar vertebra which, like the 12th thoracic vertebra, also displays malformed transverse processes (Barnes 1994, 108-17; Kernbach 2010).

90 Barnes 1994, 27-34.

91 Kernbach 2010; Rouvreau et al. 1994.

92 Weston 2008; 2012.

93 Brickley and Ives 2008; Brickley et al. 2010.
} 
contribution above), they thought that it was caused by poor maternal/carer behaviour. ${ }^{94}$ It is possible that a contributing factor was the use of swaddling for pre-mobile infants, a recommended childcare practice, as well as sun-avoidance practices, or covering of the skin by high-status females and mothers, which could then result in deficiency in the infant. ${ }^{95}$

The girl's body was placed on a bed of chalk-like material in an extended position, with her arms by her side and her head orientated to the north-west. ${ }^{96}$ Five grave goods were found. A glass aryballos (oil flask) was placed to the left of her head and an amphorisk flask to the right. A wooden casket with copper-alloy fittings and carved bone inlays (FIG. 6), one of which depicted a female figure, was placed below the feet, and a clasp knife whose ivory handle was carved to depict a leopard holding meat or prey in its forepaws (FIG. 7); the knife also had an 18-link copper-alloy chain. Nearby was a trilobate pierced handle copper-alloy key - they may have been attached but radiography was unable to determine whether this was true (FIG. 6). ${ }^{97}$
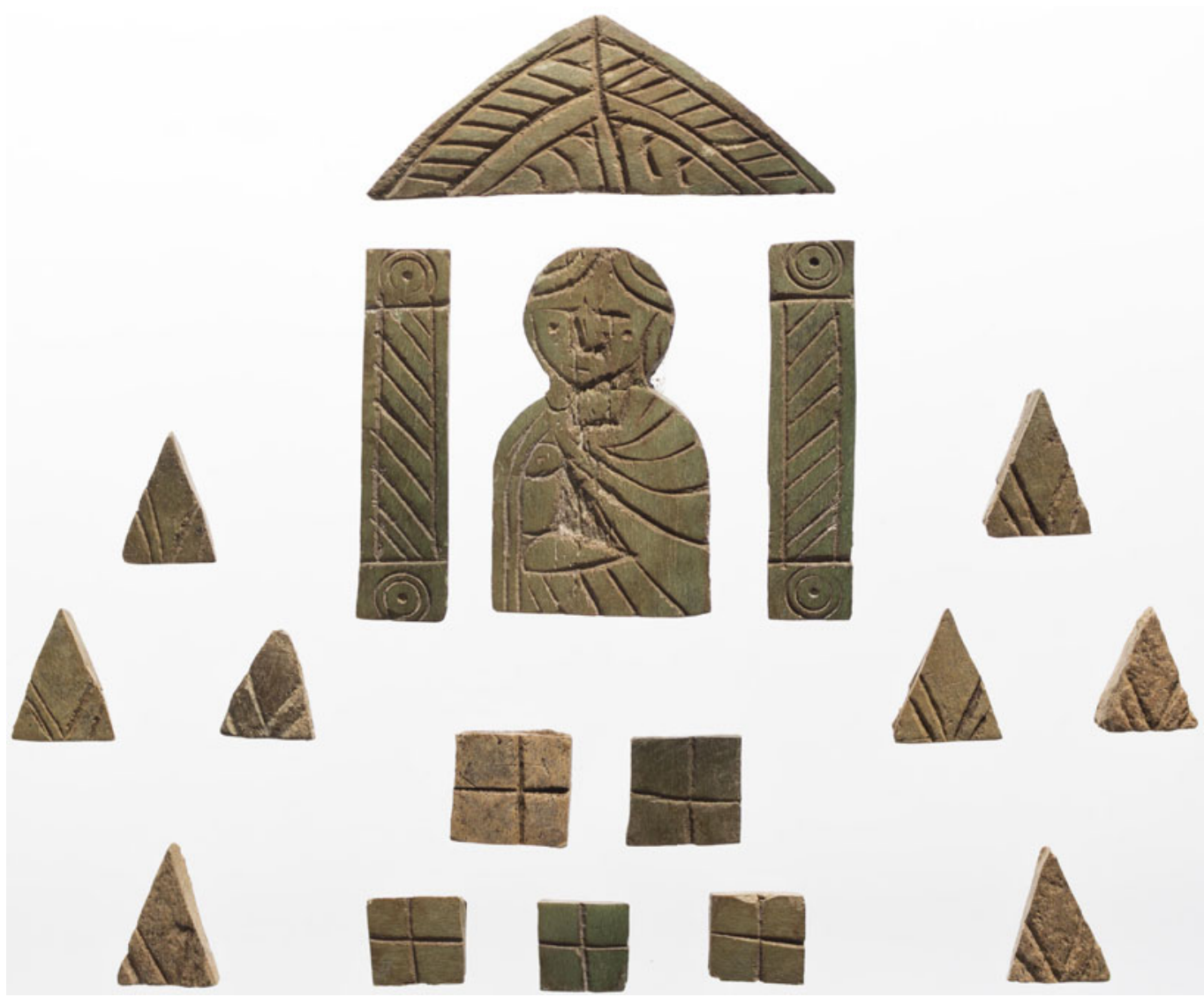

FIG. 6. Bone inlays from the wooden casket buried with LTU03 sk 385, B15. (C Pre-Construct Archaeology)

\footnotetext{
Such as drunkenness or laziness, see Soranus, Gynaecology 2.44 .

Soranus, Gynaecology 14.83; Rajakumar 2003; Baker 2010.

Ridgeway et al. 2013, 79.

ibid., 44-7.
} 


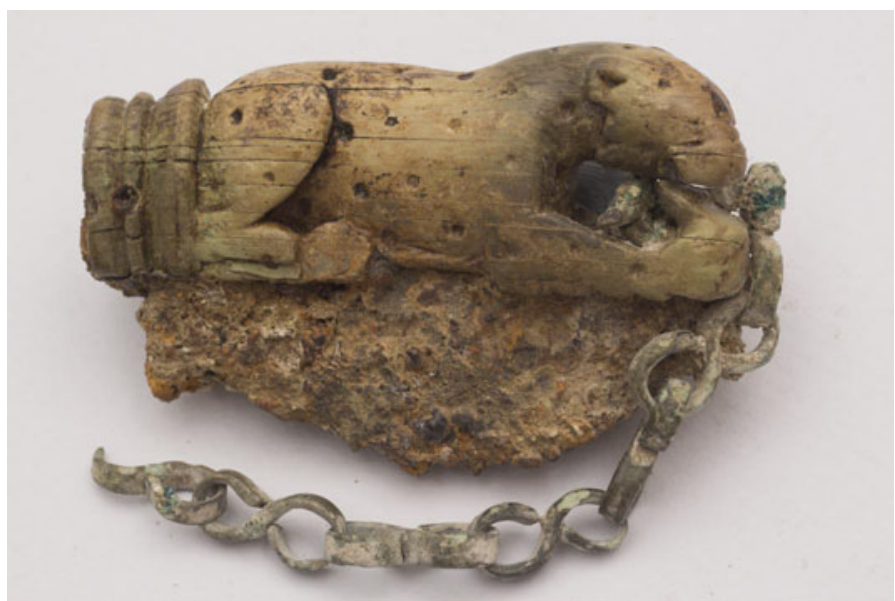

FIG. 7. Ivory leopard clasp knife buried with LTU03 sk 385, B15. (C Pre-Construct Archaeology)

The ivory leopard clasp knife handle is a rare find ${ }^{98}$ and both the quality and the material suggest that it would have been an expensive and prized possession. Such knives were probably general purpose 'pocket knives' carried on the person. That it was possibly chained together with a small key, perhaps for a jewellery box or similar, may lend some support to this interpretation as a private object ${ }^{99}$ and it is possible that the fierce creature was also envisaged as a guardian of such a box and its contents. ${ }^{100}$ It is not clear if this key fits the casket, as no lock was identified and the metal fittings were poorly preserved. ${ }^{101}$ This is a box of some quality with figurative bone inlay depicting a female bust. No close parallel can be offered but figural bone veneer of similar style appears elsewhere in Britain, although depicting male rather than female figures. ${ }^{102}$ Any contents have not survived but other small boxes from Roman female burials sometimes contain personal items such as dress accessories or toilet equipment. ${ }^{103}$ The glass vessels too are perhaps most likely to have held perfumes or oils to do

98 The only other clasp knife of comparable type from London known to the authors is a bone example from the Thames foreshore depicting a naked or partially draped male figure reported to Ian Blair and Michael Marshall of MOLA by mudlark Pat Connolly in 2016. It was found on the north bank of the Thames near Customs House (Pat Connolly, pers. comm.). In terms of closer iconographic parallels, Major 2013, 43 cites two other examples of clasp knives with supine big cat imagery from Britain, from Roughground Farm and Wroxeter. For a wider survey of feline knife handles from across the Empire, including some pieces of similar composition, see Bartus 2007, $225-9$.

99 A somewhat comparable association between a key and a piece of personalia comes from elsewhere in Southwark where a key and a cosmetic set were found corroded together, perhaps suggesting they had been strung or carried together in life. See Cowan et al. 2009, 133 and 232, fig. $99<$ S $37>$ and Jackson 2010, 150, no. 323.

100 An illuminating parallel, also from London, lends strength to this idea. This is another figurative object, a copper-alloy figurine of a sphinx, attached to a chain (Bluer et al. 2006, 155-6, fig. 107, <S54>). As sphinxes are traditionally guardians this was interpreted as a protective object perhaps originally attached to a chest or a similar object.

101 Ridgeway et al. 2013, 45.

102 Major 2013, 47 notes three male busts, from Wroxeter, Chelmsford and Great Casterton, so the fact that a female bust appears in this female burial is of some interest. No other certain examples of such figurative bone inlay are known from London but the possibility remains that a rectangular plaque with a stylised incised figure, originally published as medieval on stylistic grounds, but actually from a late Roman context, could fall into this group (Bluer et al. 2006, 159, fig. $113,<$ S39>).

103 See for example a box with jewellery, coins and gaming equipment from a burial in the Eastern Cemetery (Barber and Bowsher 2000, 165, no. B291.2) or a sliding box with bone veneer which contained an antler comb from a late Roman burial at Winchester (Rees et al. 2008, 108-11, figs 55-7). 
with bathing. Similar glass vessels have appeared in other burials and, in some parts of the Empire, are depicted on female tombstones. ${ }^{104}$ They are certainly unusual, but while their stylistic affinities are with a range of vessels from across the Empire, there are no exact parallels to suggest a source. ${ }^{105}$

Ivory objects such as the knife handle are rare finds in Roman Britain ${ }^{106}$ and may have travelled as personal possessions instead of resulting from trade. Given that the closest source of the raw material was Africa, it is noteworthy that the Lant Street girl is likely to have originated from the southern Mediterranean; another example of an individual with African ties buried with ivory objects can be cited from York. ${ }^{107}$ It is plausible to suggest a link between the presence of ivory objects and the background or life courses of these individuals, perhaps as childhood possessions or treasured family heirlooms; considerable stress was placed on the African connections of the Lant Street knife in the original publication. ${ }^{108}$

However, even if the biographies of some ivory objects might be intimately tied with personal connections to Africa and thus have personal significance, it is questionable whether they would be deliberately used to express that aspect of an individual's identity. Eckardt notes the lack of explicitly 'African subjects' depicted in ivory and argues that ivory was not symbolically linked to Africa per se. ${ }^{109}$ This knife handle, depicting a big cat found in Africa, is a possible exception to this rule but it should be remembered that leopard imagery is found across the Roman world and that these cats, and indeed elephants, are also found in Asia. ${ }^{110}$ Competing symbolic connotations include the use of leopards in Bacchic imagery, noted by Ridgeway et $a l .{ }^{111}$ and may link the find to fertility and rebirth. Venationes in the arena are another popular iconographic context for wild beasts ${ }^{112}$ and such popular imagery links this knife to other clasp knives which regularly have sporting subjects, including those relating to hunting, chariot racing and gladiatorial combat. ${ }^{113}$ Dangerous wild animals and the bloody events of the arena both have their place in funerary symbolism across the Empire. ${ }^{114}$

The funerary treatment and life history of this adolescent girl raise many potential interpretations regarding her identity. Her skeleton bears many of the dental and osteological

\footnotetext{
104 Philpott 1991; Eckardt and Crummy 2008, 37.

105 Shepherd 2013, 40-2.

106 See Eckardt 2014, 96-105. A full catalogue of ivory from Britain is being prepared by Stephen Greep (pers. comm. 2016). Perhaps unsurprisingly given the cosmopolitan nature of the city and the scale of excavation, a relatively high proportion of ivory finds are from Roman London. See for example several other knife handles (Greep 1982, 99, fig. 5; Hill and Rowsome 2011, 81, fig. 74. <S221>; Marshall and Wardle in prep.); sword handle components and scabbard slides (Greep 1983, figs 21.2 and 120.2; Bluer et al. 2006, 157, fig. 109 <S32>; Marshall and Wardle in prep.). For other ivory finds from burials in the city see a late Roman female inhumation buried with ivory bangles (Barber and Bowsher 2000, 147) and an ivory torso associated with a third- to fourth-century child's burial (ibid., 188).

107 The so-called 'Ivory bangle Lady'; Leach et al. 2010.

108 Ridgeway et al. 2013, 113-14. Stylistic similarities with a single unpublished clasp knife handle from Carthage, depicting a lioness not a leopard, are briefly noted by Major 2013, 47.

109 Eckardt 2014, 104.

110 A fact well known to the Romans. See Toynbee 1973, 82.

111 Ridgeway et al. 2013, 114; see also Toynbee 1973, 84-6. Several depictions of leopards from Roman London have been interpreted in this light and Toynbee notes the explicit connection between Bacchus and a leopard that can be seen in a sculpture from the Walbrook Mithraeum.

112 Toynbee 1973, 82-4.

113 For summaries of gladiator knives see Bartus 2010; Bartus and Grimm 2010. To the list of British finds may be added a more recent find from Kent reported in Cotton et al. 2016, 34, fig. 34, <S28>. For charioteers see Köhne et al. 2000, fig. 101; Bartus 2007, 206-8. For hunting scenes see Bartus 2007, 233-7.

114 For the funerary connotations of lions see Hunter 2003. For a discussion of death and gladiatorial symbolism in conjunction with another burial from Southwark see Bateman 2008.
} 
changes associated with enslavement though these are not exclusive to that status group, ${ }^{115}$ while her grave goods suggest an individual of comparatively high status. Her childhood journey from the southern Mediterranean to Britain, and her careful burial and the choice of accompanying objects included with her, emphasise the mutability of identity in the Roman Empire, particularly in atypical 'melting pot' settlements where diverse ethnicities, cultures, status groups and occupations lived together and created new 'Roman' places; overall, she reflects Londinium, a unique settlement in Roman Britain.

\section{CONCLUSIONS}

This project was driven by the need to provide new and engaging museum content and to spark the interest of our audience groups, particularly school children. Although previous exhibitions have demonstrated that for the majority of our audiences we can achieve this using information gained from standard osteological analyses, ${ }^{116}$ the ability to tell a visitor that a particular person in the Museum's holdings had brown eyes and black hair has proven very powerful. These personal details provided our visitors with an immediate connection to these Roman Londoners and were instrumental in achieving the extensive national and international media coverage for the Museum. ${ }^{117}$

The timing of the exhibition, in the autumn of 2015, greatly influenced how some areas of the media responded to the 'stories' about these four individuals. That year was the beginning of the 'Migrant crisis' across Europe, with over a million migrants and people fleeing war in Syria and arriving in Europe, as well as the early stages of the Brexit campaign. ${ }^{118}$ Consequently, the focus in the tabloid press was on their identity as migrants and the movement of people across Europe in the past, themes which were negatively expressed in some of the public online comments. ${ }^{19}$ This trend has not abated, as new information about the potential Asian and Black ancestry of other Roman individuals in the Museum's collections published in 2016 has received similar attention in the tabloid media. ${ }^{120}$ Such responses serve to underscore the role that heritage plays with respect to national identity and the ethical challenges that archaeology continues to face. ${ }^{121}$

Undertaking an aDNA study also raised a number of ethical and practical issues. In particular, how to manage the relationship between the information deposited with the genetic databank and the individual human remains in our collection, and our curatorial responsibility to ensure that the personal information was shared in a way that maintained their dignity and treated them with respect. This was most pertinent for the Harper Road burial, where we took the decision to respect and maintain the identity created and reflected in their burial treatment. ${ }^{122}$

The experience of undertaking a multidisciplinary study served to further underline the need for these different techniques to be used in combination when investigating past identities. The

\footnotetext{
115 For example, the presence of rickets, enamel hypoplastic defects and young age-at-death, see Redfern forthcoming.

116 For example, 'Skeletons: London's Buried Bones' which was a collaborative exhibition held at the Wellcome Collection in 2008 .

117 The findings were included on the BBC's 6 o'clock news and other content, also in major newspapers and online content.

118 http://www.bbc.co.uk/news/world-europe-34131911; http://www.bbc.co.uk/news/politics/uk_leaves_the_eu.

119 http://www.dailymail.co.uk/sciencetech/article-3361146/The-Roman-Woman-MALE-DNA-Analysis-2-000year-old-skeleton-reveals-physical-female-traits-genetically-man.html.

$120 \mathrm{http}: / / \mathrm{www}$.dailymail.co.uk/sciencetech/article-3803648/A-meeting-two-ancient-empires-Chinese-skeletonsRoman-cemetery-promise-rewrite-history.html.

121 Amongst others, Díaz-Andreu and Champion 2015

122 See also Tarlow's 2006 discussion of these themes.
} 
mtDNA results were very broad and required the mobility isotopes to better understand their significance. The aDNA evidence for disease was disappointing ${ }^{123}$ but did confirm the osteological analyses. As stated above, however, the most successful aspect of the aDNA aspect of the project in terms of public engagement and the creation of content was the determination of hair and eye colour.

Our investigation into the lives of these four people shows that Londinium was a dynamic and diverse settlement, which despite being on the fringes of the Empire was deeply connected in terms of people and material culture because of the unique role it played in the province. Each of the four people shows how the structure and organisation of the Roman Empire enabled individuals and their ancestors to travel vast distances ${ }^{124}$ and how these choices and resulting hierarchies created people with diverse and complex ancestries and identities. The Lant Street and Harper Road burials further emphasise the intense heterogeneity in the burial record of the Empire, as these individuals do not conform to how other migrants and locals are treated in Britain. ${ }^{125}$

Our research has provided the first archaeological evidence for an individual with a sex chromosome disorder and in light of recent finds we are able to provide a new interpretation of the unusual items included in their burial at Harper Road, particularly the torc which appears to reflect the importance of asserting indigenous regional identities in response to the Claudian invasion. The importance of revisiting previously published data is proven in our reconsideration of the girl from Lant Street, where we suggest that her connections to Africa are far from clear-cut. Above all, this study demonstrates the important and unique contribution that bioarchaeology can make. ${ }^{126}$

\title{
ACKNOWLEDGEMENTS
}

We are most grateful to the MoL donors, Durham and McMaster Universities who provided the financial and practical support to undertake the research necessary for this exhibition. The research presented here reflects many years of work and we are grateful for the help, guidance and advice of: Nichola Arthur, David Bowsher, Nikki Braughton, John Chase, Jon Cotton, Jayne Davis, Jane Evans, Becky Gowland, Darren Gröcke, Helen Ashworth, Jenny Hall, Joseph Hefner, Heritage Network, Kristina Killgrove, Lucie Johnson, Caroline McDonald, Andrew Millard, Janet Montgomery, John Pearce, Lindsay Powell, Victoria Ridgeway, Heidi Shaw, Roy Stephenson and Angela Wardle.

\author{
Centre for Human Bioarchaeology, Museum of London (R.C.R.) \\ rredfern@museumoflondon.org.uk \\ Museum of London Archaeology, London (M.M.) \\ mmarshall@mola.org.uk \\ McMaster University, Ontario, Canada (K.E. and H.N.P.) \\ kmeaton@gmail.com \\ poinarh@mcmaster.ca
}

\footnotetext{
123 It was hoped that we would find evidence for infectious diseases, such as tuberculosis or leprosy.

124 It is not clear whether their mobility was from choice, occupation or enslavement.

125 These two individuals do not fit the four categories proposed by Eckardt et al. 2014, 4 .

126 As defined by Martin et al. 2013, 2, 'Bioarchaeology is the study of ancient and historic human remains in a richly configured context that includes all possible reconstructions of the cultural and environmental variables relevant to the interpretations drawn from those remains ... bioarchaeology illuminates human behaviour'.
} 


\section{BIBLIOGRAPHY}

Andreasen, J.O., Bakland, L.K., Flores, M.T., Andreasen, F.M., and Andersson, L. 2011: Traumatic Dental Injuries: A Manual (3rd edn), Oxford

Arnold, B. 2002: “Sein and werden": gender as a process in mortuary ritual', in S.M. Nelson and M. Rosen-Ayalon (eds), In Pursuit of Gender: Worldwide Archaeological Processes, Oxford, 239-56

Arthur, N., Gowland, R.L., and Redfern, R.C. 2016: 'Coming of age in Roman Britain: osteological evidence for pubertal timing', American Journal of Physical Anthropology 159, 698-713

Baker, P. 2010: 'Children's health and science', in R. Laurence and M. Harlow (eds), A Cultural History of Childhood and Family in Antiquity, Oxford, 153-70

Barber, B., and Bowsher, D. (eds) 2000: The Eastern Cemetery of Roman London. Excavations 1983-1990, MoLAS Monograph 4, London

Barnes, E. 1994: Developmental Defects of the Axial Skeleton in Paleopathology, Colorado

Bartus, D. 2007: A római kori csontfaragás és a kismüvészetek összefüggései (Roman bone carving and the minor arts), unpub. $\mathrm{PhD}$ thesis, Eötvös Loránd University of Sciences, Budapest

Bartus, D. 2010: 'Les manches de couteau à représentation de gladiateur de l'époque romaine', in L. Borhy (ed.), Studia Celtica Classica et Romana Nicolae Szabó septuagesimo dedicate, Budapest, 27-49

Bartus, D., and Grimm, J. 2010: 'A knife-handle from Caerwent (Venta Silurum) depicting gladiators', Britannia 41, 321-4

Bass, W.M. 2005: Human Osteology: A Laboratory and Field Manual, Columbia

Bateman, N. 2008: 'Death, women and the afterlife: some thoughts on a burial in Southwark', in Clark et al. 2008, 162-6

Bluer, R., Brigham, T., and Nielsen, R. 2006: Roman and Later Development East of the Forum and Cornhill: Excavations at Lloyd's Register, 71 Fenchurch Street, City of London, MoLAS Monograph 30, London

Bonsall, L. 2014: 'A comparison of female and male oral health in skeletal populations from late Roman Britain: implications for diet', Archives of Oral Biology 59.12, 1279-300

Brickley, M., and Ives, R. 2008: The Bioarchaeology of Metabolic Bone Disease, London

Brickley, M., and McKinley, J. (eds) 2004: Guidance to the Standards for Recording Human Skeletal Remains, Institute of Field Archaeologists, British Association of Biological Anthropology and Osteoarchaeology, Reading

Brickley, M., Mays, S., and Ives, R. 2010: 'Evaluation and interpretation of residual rickets deformities in adults', International Journal of Osteoarchaeology 20, 54-66

Brink, O. 2009: 'When violence strikes the head, neck and face', Journal of Trauma 67.1, 147-51

Buckberry, J., and Chamberlain, A.T. 2002: 'Age estimation from the auricular surface of the ilium: a revised method', American Journal of Physical Anthropology 113, 231-9

Budd, P. 2003: 'Combined O-, Sr- and Pb-isotope analysis of dental tissues from a Neolithic individual from Shepperton and an Iron Age individual from Southwark, London', unpub. report, Archaeotrace Ltd

Buikstra, J.E., and Ubelaker, D.H. (eds) 1994: Standards for Data Collection from Human Skeletal Remains, Arkansas Archaeological Survey Research Series 44, Arkansas

Butler, E., and Li, R. 2014: 'Genetic markers for sex identification in forensic DNA analysis', Journal of Forensic Investigation 2.3, 10-19

Butler, J., and Ridgeway, V. (eds) 2009: Secrets of the Gardens: Archaeologists Unearth the Lives of Roman Londoners at Drapers' Gardens, Pre-Construct Archaeology, Brockley

Catalano, P., Verginelli, F., Coia, V., Destro Bisol, G., Nanni, A., Ottini, L., Palmirotta, R., Santandrea, E., Rea, R., and Costantini, R.M. 2001: 'L'Ipogeo di Trebio Giusto. Un'indagine antropologica dallo scavo alla ricerca paleogenetica', Bullettino dell'Istituto Archeologico Germanico Sezione Romana 108, 366-72

Clark, J., Cotton, J., Hall, J., Sherris, R., and Swain, H. (eds) 2008: Londinium and Beyond: Essays on Roman London and its Hinterland for Harvey Sheldon, CBA Research Report 156, York

Connell, B., and Rauxloh, P. 2006: A Rapid Method for Recording Human Skeletal Data, Museum of London, London

Cotton, J. 2008: 'Harper Road, Southwark: an early Roman burial revisited', in Clark et al. 2008, 151-61

Cotton, J., with Betts, I., Henderson, M., Macpherson Grant, N., Marshall, M., Monteil, G., Morris, J., Pipe, A., Stewart, K., and Thorp, A. 2016: A Prehistoric and Roman Settlement at Tothill Street, Minster in Thanet, Kent Archaeological Reports, http://www.kentarchaeology.org.uk/10/042.pdf 
Cowan, C., Seeley, F., Wardle, A., Westman, A., and Wheeler, L. 2009: Roman Southwark Settlement and Economy, MOLA Monograph 42, London

Crummy, N. 1983: The Roman Small Finds from Excavations in Colchester 1971-9, Colchester Archaeological Report 2, Colchester

Crummy, N. 2005a: 'From bracelets to battle-honours: military armillae from the Roman conquest of Britain', in Crummy 2005b, 93-105

Crummy, N. (ed.) 2005b: Image, Craft and the Classical World. Essays in Honour of Donald Bailey and Catherine Johns, Monographies Instrumentum 29, Montagnac

Crummy, N. 2016: 'A hoard of military awards, jewellery and coins from Colchester', Britannia 47, 1-28

Devault, A., Jaing, A., Gardner, C., Porter, S., Enk, T.M., Thissen, J., Allen, J., Borucki, M., DeWitte, S., Dhody, A., McLoughlin, K., and Poinar, H.N. 2014: 'Ancient pathogen DNA in archaeological samples detected with a microbial detection array', Nature Scientific Reports 4, 4245, doi: 10.1038/srep04245

Díaz-Andreu, M., and Champion, T. (eds) 2015: Nationalism and Archaeology in Europe, London

Eckardt, H. 2014: Objects and Identities in Roman Britain and the North-Western Provinces, Oxford

Eckardt, H., and Crummy, N. 2008: Styling the Body in Late Iron Age and Roman Britain: A Contextual Approach to Toilet Instruments, Monographies Instrumentum 36, Montagnac

Eckardt, H., Müldner, G., and Lewis, M. 2014: 'People on the move in Roman Britain', World Archaeology $46.4,1-17$

Fejerskov, O., Guldager Bilde, P., Bizzarro, M., Connelly, J.N., Skovhus Thomsen, J., and Nyvad, B. 2012: 'Dental caries in Rome, 50-100 AD', Caries Research 46.5, 467-73

Geller, P.L. 2017: The Bioarchaeology of Socio-Sexual Lives. Queering Common Sense about Sex, Gender, and Sexuality, Switzerland

Genovés, S. 1959: 'L'estimation des iliac ences sexuelles dans l'os coxal; differences métriques et iliac ences morphlogiques', Bulletins et Mémoires de la Société d'Anthropologie de Paris 10, 3-95

Giles, M. 2012: A Forged Glamour: Landscape, Identity and Material Culture in the Iron Age, Oxford

Gowland, R.L., and Knüsel, C.J. 2006a: 'Introduction', in Gowland and Knüsel 2006b, ix-xiv

Gowland, R.L., and Knüsel, C.J. (eds) 2006b: Social Archaeology of Funerary Remains, Oxford

Greep, S.J. 1982: 'Two early Roman handles from the Walbrook, London', Archaeological Journal 139, 91-100

Greep, S.J. 1983: Objects of Animal Bone, Antler, Ivory and Teeth from Roman Britain, unpub. PhD thesis, University of Cardiff

Greep, S.J. 2004: 'Bone and antler veneer', in H.E.M. Cool (ed.), The Roman Cemetery at Brougham, Cumbria: Excavations 1966-67, Britannia Monograph 21, London, 273-82

Hall, J. 1996: 'The cemeteries of Roman London', in J. Bird, M. Hassall and H. Sheldon (eds), Interpreting Roman London. Papers in Memory of Hugh Chapman, Oxbow Monograph 58, Oxford, 57-84

Hall, J., and Wardle, A. 2005: 'Dedicated followers of fashion? Decorative bone hairpins from Roman London', in Crummy 2005b, 173-8

Hamlin, C. 2007: The Material Expression of Social Change: The Mortuary Correlates of Gender and Age in Late Pre-Roman Iron Age and Roman Dorset, unpub. PhD thesis, University of Wisconsin, Milwaukee

Harward, C., Powers, S., and Watson, S. (eds) 2015: The Upper Walbrook Valley Cemetery of Roman London: Excavations at Finsbury Circus, City of London, 1987-2007, Museum of London Archaeology Monograph Series 69, London

Hefner, J.T., and Ousley, S.T. 2014: 'Statistical classification methods for estimating ancestry using morphoscopic traits', Journal of Forensic Science 59.4, 883-90

Hefner, J.T., Ousley, S.D., and Dirkmaat, D.C. 2012: 'Morphoscopic traits and the assessment of ancestry', in D.C. Dirkmaat (ed.), A Companion to Forensic Anthropology, Chichester, 287-310

Hill, J., and Rowsome, P. 2011: Roman London and the Walbrook Stream Crossing: Excavations at 1 Poultry and Vicinity, City of London, Museum of London Archaeology Monograph Series 37, London

Hillson, S. 2005: Dental Anthropology (2nd edn), Cambridge

Holder, N. 2007: 'Mapping the Roman inscriptions of London', Britannia 38, 13-34

Hunter, F. 2003: 'Funerary lions in Roman provincial art', in P. Noelke (ed.), Romanisation und Resistenz in Plastik, Architektur und Inschriften der Provinzen des Imperium Romanum: Neue Funde und Forschungen, 59-67

Hunter, F. 2008: 'Celtic art in Roman Britain', in D. Garrow, C. Gosden and J.D. Hill (eds), Rethinking Celtic Art, Oxford, 129-45 
Hunter, F. 2010: 'Changing objects in changing worlds: dragonesque brooches and beaded torcs', in S. Worrell, G. Egan, J. Naylor, K. Leahy and M. Lewis (eds), A Decade of Discovery: Proceedings of the Portable Antiquities Scheme Conference 2007, BAR British Series 520, Oxford, 91-107

Hwang, K., and You, S.H. 2010: 'Analysis of facial bone fractures: an 11-year study of 2,094 patients', Indian Journal of Plastic Surgery 43.1, 42-8

Jackson, R. 2010: Cosmetic Sets of Late Iron Age and Roman Britain, London

Johns, C. 2006: 'Iron Age sword and mirror cist burial from Bryher, Isles of Scilly', Cornish Archaeology $41.2,1-80$

Jordan, A. 2016: 'Her mirror, his sword: unbinding binary gender and sex assumptions in Iron Age British mortuary traditions', Journal of Archaeological Method and Theory 23.3, 870-99

Joy, J. 2007: Reflections on the Iron Age: Biographies of Mirrors, unpub. PhD thesis, University of Southampton

Joy, J. 2010: Iron Age Mirrors a Biographical Approach, BAR British Series 518, Oxford

Kernbach, K.J. 2010: 'Tarsal coalitions: etiology, diagnosis, imaging, and stigmata', Clinics in Podiatric Medicine and Surgery 27.1, 105-17

Knudson, K., and Stojanowski, C.M. 2008: 'New directions in bioarchaeology', Journal of Archaeological Research 16.4, 397-432

Köhne, E., Ewigleben, C., and Jackson, R. 2000: Gladiators and Caesars: The Power of Spectacle in Ancient Rome, Berkeley

Kotowicz, M.A. 2004: 'Paget disease of bone. Diagnosis and indications for treatment', Australian Family Physician 33.3, 127-31

Leach, S., Lewis, M., Chenery, C., Müldner, G., and Eckardt, H. 2009: 'Migration and diversity in Roman Britain: a multidisciplinary approach to immigrants in Roman York, England', American Journal of Physical Anthropology 140, 546-61

Leach, S., Eckardt, H., Chenery, C., Müldner, G., and Lewis, M. 2010: 'A "lady" of York: migration, ethnicity and identity in Roman York', Antiquity 84, 131-45

Lees, D., Woodger, A., and Orton, C. 1989: 'Excavations in the Walbrook Valley', London Archaeologist $6.5,115-19$

Lloyd-Morgan, G. 1981: Description of the Collections in the Rijksmuseum G.M. Kamm at Nijmegen 9: The Mirrors, Nijmegen

Major, H. 2013: 'Metal and bone objects', in Ridgeway et al. 2013, 43-8

Maloney, C., and de Moulins, D. (eds) 1990: The Archaeology of Roman London Volume 1: The Upper Walbrook in the Roman Period, CBA Research Report 69, London

Marciniak, S., Prowse, T.L., Herring, D.A., Klunk, J., Kuch, M., Duggan, A.T., Bondioli, L., Holmes, E.C., and Poinar, H.N. 2016: 'Plasmodium falciparum malaria in 1st-2nd century CE southern Italy', Current Biology 26.23, R1220-1222

Marshall, M., and Wardle, A. in prep.: The Roman Small Finds, Coins, Glass Vessels and Textiles from Bloomberg, London, MOLA Monograph Series

Martin, D.L., Harrod, R.P., and Pérez, V.R. 2013: Bioarchaeology. An Integrated Approach to Working with Human Remains, Switzerland

Martiniano, R., Caffell, A., Holst, M., Hunter-Mann, K., Montgomery, J., Müldner, G., McLaughlin, R.L., Teasdale, M.D., van Rheenen, W., Veldink, J.H., van der Berg, L.H., Hardiman, O., Carroll, M., Roskams, S., Oxley, J., Morgan, C., Thomas, M.G., Barnes, I., McDonnell, C., Collins, M.J., and Bradley, D.G. 2016: 'Genomic signals of migration and continuity in Britain before the Anglo-Saxons', Nature Communications $7.10326,1-8$

Mays, S. 2006: 'The osteology of monasticism in medieval England', in Gowland and Knüsel 2006b, 179-89

Mazieres, B. 2013: 'Diffuse idiopathic skeletal hyperostosis (Forestier-Rotes-Querol disease): what's new?', Joint Bone Spine 80.5, 466-70

McIlvaine, B.K. 2015: 'Implications of reappraising the iron-deficiency anemia hypothesis', International Journal of Osteoarchaeology 25, 997-1000

Mitchell, P.D. 2016: 'Human parasites in the Roman world: health consequences of conquering an empire', Parasitology 8, 1-11

Morales, A.A., Valdazo, P., Corres, J., Talbot, J.R., Perez, F., and Baylink, D.J. 1993: 'Coexistence of Paget's bone disease and diffuse idiopathic skeletal hyperostosis in males', Clinical and Experimental Rheumatology 11.4, 361-5 
Nowakowski, J., Gwilt, A., Megaw, V., and La Niece, S. 2009: 'A Late Iron Age neck-ring from Pentire, Newquay, Cornwall, with a note on the find from Boverton, Vale of Glamorgan', Antiquaries Journal $89,35-52$

Perring, D. 2004: Roman London, London

Perring, D. 2015: 'Recent advances in the understanding of Roman London', in M. Fulford, and N. Holbrook (eds), The Towns of Roman Britain: The Contribution of Commercial Archaeology Since 1990, Britannia Monograph 27, London, 20-43

Phenice, T. 1969: 'A newly developed visual method of sexing the os pubis', American Journal of Physical Anthropology 30, 297-301

Philpott, R. 1991: Burial Practices in Roman Britain, BAR British Series 219, Oxford

Pope, R., and Ralston, I. 2012: 'Approaching sex and status in Iron Age Britain with reference to the nearer Continent', in T. Moore and X.-T. Armada (eds), Western Europe in the First Millennium BC, Oxford

Powell, L.A. 2015: Childhood Health and Diet in Roman London: The Palaeodemographic, Palaeopathological and Isotopic Evidence, unpub. $\mathrm{PhD}$ thesis, University of Durham

Powell, L.A., Redfern, R.C., and Millard, A.R. 2014: 'Infant feeding practices in Roman London: the isotopic evidence', in P.M. Carroll and E.-J. Graham (eds), Infant Health and Death in Roman Italy and Beyond, Journal of Roman Archaeology Supplementary Series 96, Portsmouth, RI, 89-110

Powers, N. (ed.) 2012: Human Osteology Method Statement, Museum of London http://www. museumoflondon.org.uk/application/files/4814/5633/5269/osteology-method-statement-revised-2012.pdf

Rajakumar, K. 2003: 'Vitamin D, cod-liver oil, sunlight and rickets: a historical perspective', Pediatrics $112.2, \mathrm{e} 132$

Redfern, R.C. forthcoming: 'Blind to chains? The potential of bioarchaeology for identifying the enslaved of Roman Britain', Britannia

Redfern, R.C., and Bonney, H. 2014: 'Headhunting and amphitheatre combat in Roman London, England: new evidence from the Walbrook Valley', Journal of Archaeological Science 43, 214-26

Redfern, R.C., and DeWitte, S. 2011: 'A new approach to the study of Romanization in Britain: a regional perspective of cultural change in late Iron Age and Roman Dorset using the Siler and Gompertz-Makeham models of mortality', American Journal of Physical Anthropology 144, 269-85

Redfern, R.C., DeWitte, S.N., Pearce, J., Hamlin, C., and Egging Dinwiddy, K. 2015: 'Urban-rural differences in Roman Dorset, England: a bioarchaeological perspective on Roman settlements', American Journal of Physical Anthropology 157, 107-20

Redfern, R.C., Gröcke, D.R., Millard, A.R., Ridgeway, V., Johnson, L., and Hefner, J.T. 2016: 'Going south of the river: a multidisciplinary analysis of ancestry, mobility and diet in a population from Roman Southwark, London', Journal of Archaeological Science 74, 11-22

Rees, H., Crummy, N., Ottaway, P.J., and Dunn, G. 2008: Artefacts and Society in Roman and Medieval Winchester. Small Finds from the Suburbs and Defences, 1971-1986, Winchester

Reitsema, L.J., and McIlvaine, B.K. 2014: 'Reconciling "stress" and "health" in physical anthropology: what can bioarchaeologists learn from the other subdisciplines?', American Journal of Physical Anthropology $155,181-5$

Ridgeway, V., Leary, K., and Sudds, B. (eds) 2013: Roman Burials in Southwark. Excavations at 52-56 Lant Street and 56 Southwark Bridge Road, London SE1, PCA Monograph 17, London

Roberts, A., Peters, T.J., and Robson Brown, K.L. 2007: 'New light on old shoulders: palaeopathological patterns of arthropathy and enthesopathy in the shoulder complex', Journal of Anatomy 211.4, 485-92

Rogers, T.L. 1999: 'A visual method of determining the sex of skeletal remains using the distal humerus', Journal of Forensic Science 44, 57-60

Rogers, T.L. 2009: 'Sex determination of adolescent skeletons using the distal humerus', American Journal of Physical Anthropology 140, 143-8

Rouvreau, P., Pouliquen, J.C., Langlais, J., Glorion, C., and de Cerqueira Daltro, G. 1994: 'Synostosis and tarsal coalitions in children. A study of 68 cases in 47 patients', Revue de Chirurgie Orthopédique et Réparatrice de L'Appareil Moteur 80.3, 252-60

Schutkowski, H. 1993: 'Sex determination of infant and juvenile skeletons. I. Morphological features', American Journal of Physical Anthropology 90, 199-205

Seow, W.K. 2014: 'Developmental defects of enamel and dentine: challenges for basic science research and clinical management', Australian Dental Journal 59.1, 143-54 
Shapland, F., and Lewis, M.E. 2013: 'Brief communication: a proposed osteological method for the estimation of pubertal stage in human skeletal remains', American Journal of Physical Anthropology 151, 302-10

Shapland, F., and Lewis, M.E. 2014: 'Brief communication: a proposed method for the assessment of pubertal stage in human skeletal remains using cervical vertebrae maturation', American Journal of Physical Anthropology 153, 144-53

Shaw, H., Montgomery, J., Redfern, R., Gowland, R., and Evans, J. 2016: 'Identifying migrants in Roman London using lead and strontium stable isotopes', Journal of Archaeological Science 66, 57-68

Shepherd, J. 2013: 'Glass', in Ridgeway et al. 2013, 36-43

Shoemaker, N. (ed.) 2012: Negotiators of Change. Historical Perspectives on Native American Women, London

Sofaer, J.R. 2006: The Body as Material Culture. A Theoretical Osteoarchaeology, Cambridge

Soranus: Soranus' Gynecology (trans. O. Temkin, 1991), Baltimore

Spencer, R. 2010: Testing Hypotheses about Diffuse Idiopathic Skeletal Hyperostosis (DISH) Using Stable Isotopes and Other Methods, unpub. PhD thesis, University of Durham

Stead, I.M., and Rigby, V. 1986: Baldock: The Excavation of a Roman and Pre-Roman Settlement 19681972, Britannia Monograph 7, London

Stead, I.M., and Rigby, V. 1989: Verulamium: The King Harry Lane Site, London

Sumer, A.P., and Zengin, A.Z. 2005: 'An unusual presentation of talon cusp', British Dental Journal 199.7, 429-30

Targino, A.G., Rosenblatt, A., Oliveira, A.F., Chaves, A.M., and Santos, V.E. 2011: 'The relationship of enamel defects and caries: a cohort study', Oral Diseases 17.4, 420-6

Tarlow, S. 2006: 'Archaeological ethics and the people of the past', in C. Scarre and G. Scarre (eds), The Ethics of Archaeology: Philosophical Perspectives on Archaeological Practice, Cambridge, 199-218

Terizi, R. 2014: 'Extraskeletal symptoms and comorbidities of diffuse skeletal hyperostosis', World Journal of Clinical Cases 2.9, 422-5

Tomlin, R. 2016: Roman London's First Voices: Writing Tablets from the Bloomberg Excavations, 2010-14, MOLA Monograph 72, London

Toynbee, J.M.C. 1973: Animals in Roman Life and Art, London

van der Merwe, A.E., Maat, G.J., and Watt, I. 2012: 'Diffuse idiopathic skeletal hyperostosis: diagnosis in a palaeopathological context', Homo 63.3, 202-15

von Mercklin, E. 1940: 'Römische Klappmessergriffe', in Festchrift Victor Hoffiller (Serta Hoffilleriana) Zagreb, 339-52

Walker, P.L. 1995: 'Problems of preservation and sexism in sexing: some lessons from historical collections for palaeodemographers', in S. Saunders and A. Herring (eds), Grave Reflections. Portraying the Past through Cemetery Studies, Toronto, 31-47

Walker, P.L., Bathurst, R.R., Richman, R., Gjerdrum, T., and Andrushko, V.A. 2009: 'The causes of porotic hyperostosis and cribra orbitalia: a reappraisal of the iron-deficiency-a hypothesis', American Journal of Physical Anthropology 139, 109-25

Wallace, L. 2015: The Origin of Roman London, Cambridge

Walsh, S., Liu, F., Wollstein, A., Kovatsi, L., Ralf, A., Kosiniak-Kamysz, A., Branicki, W., and Kayser, M. 2013: 'The HIrisPlex system for simultaneous prediction of hair and eye colour from DNA', Forensic Science International. Genetics 7.1, 98-115

Wardle, A. forthcoming, in H. Ashworth (ed.), A Late Iron Age and Romano-British Cemetery at California, Baldock, Herts

Warne, G.L., and Raza, J. 2008: 'Disorders of sex development (DSDs), their presentation and management in different cultures', Reviews in Endocrine and Metabolic Disorders 9, 227-36

Weaver, D.S. 1980: 'Sex differences in the ilia of known sex and age sample of fetal and infant skeletons', American Journal of Physical Anthropology 6, 199-208

Weston, D. 2008: 'Investigating the specificity of periosteal reactions in pathology museum specimens', American Journal of Physical Anthropology 137, 48-59

Weston, D. 2012: 'Non-specific infection in palaeopathology: interpreting periosteal reactions', in A. L. Grauer (ed.), Companion to Paleopathology, New York, 492-512

Whytehead, R. 1986: 'The excavation of an area within a Roman cemetery at West Tenter Street, London E1', Transactions London and Middlesex Archaeological Society 37, 23-68

WORD 2016: Roman Data, Museum of London 